\title{
Properties of Halococcus salifodinae, an Isolate from Permian Rock Salt Deposits, Compared with Halococci from Surface Waters
}

Andrea Legat ${ }^{1}$, Ewald B. M. Denner ${ }^{2}$, Marion Dornmayr-Pfaffenhuemer ${ }^{1}$, Peter Pfeiffer ${ }^{3}$, Burkhard Knopf ${ }^{4}$, Harald Claus ${ }^{3}$, Claudia Gruber ${ }^{1}$, Helmut König ${ }^{3}$, Gerhard Wanner ${ }^{5}$ and Helga Stan-Lotter ${ }^{1, *}$

1 Department of Molecular Biology, University of Salzburg, Billrothstr. 11, 5020 Salzburg, Austria; E-Mails: Andrea.Legat@gmx.at (A.L.); marion.dornmayr@gmail.com (M.D.-P.);

Claudia.Gruber@sbg.ac.at (C.G.)

2 Medical University Vienna, Währingerstrasse 10, 1090 Wien, Austria;

E-Mail: dennerebm@yahoo.de

3 Institute of Microbiology and Wine Research, Johannes Gutenberg-University, 55099 Mainz, Germany; E-Mails: ppfeiffe@uni-mainz.de (P.P.); hclaus@uni-mainz.de (H.C.); hkoenig@uni-mainz.de (H.K.)

4 Frauenhofer-Institut für Molekularbiologie und Angewandte Ökologie, 57392 Schmallenberg, Germany; E-Mail: burkhard_knopf@hotmail.com

5 LMU Biocenter, Ultrastructural Research, Grosshadernerstrasse 2-4, 82152 Planegg-Martinsried, Germany; E-Mail: Wanner@1rz.uni-muenchen.de

* Author to whom correspondence should be addressed; E-Mail: helga.stan-lotter@sbg.ac.at; Tel.: +43699 81223362; Fax: +436228044 7209.

Received: 1 January 2013; in revised form: 7 February 2013 / Accepted: 14 February 2013 / Published: 28 February 2013

Abstract: Halococcus salifodinae $\mathrm{BIp}^{\mathrm{T}} \mathrm{DSM} 8989^{\mathrm{T}}$, an extremely halophilic archaeal isolate from an Austrian salt deposit (Bad Ischl), whose origin was dated to the Permian period, was described in 1994. Subsequently, several strains of the species have been isolated, some from similar but geographically separated salt deposits. Hcc. salifodinae may be regarded as one of the most ancient culturable species which existed already about 250 million years ago. Since its habitat probably did not change during this long period, its properties were presumably not subjected to the needs of mutational adaptation. Hcc. salifodinae and other isolates from ancient deposits would be suitable candidates for testing hypotheses on prokaryotic evolution, such as the molecular clock concept, or the net-like 
history of genome evolution. A comparison of available taxonomic characteristics from strains of Hcc. salifodinae and other Halococcus species, most of them originating from surface waters, is presented. The cell wall polymer of Hcc. salifodinae was examined and found to be a heteropolysaccharide, similar to that of Hcc. morrhuae. Polyhydroxyalkanoate granules were present in Hcc. salifodinae, suggesting a possible lateral gene transfer before Permian times.

Keywords: Halococcus species; Halococcus salifodinae; haloarchaea; Permian salt deposit; cell wall polymer; polyhydroxyalkanoate; prokaryotic evolution

\section{Introduction}

Halococcus salifodinae $\mathrm{BIp}^{\mathrm{T}}$ DSM $8989^{\mathrm{T}}$ was obtained as a viable isolate from Permian rock salt deposits of a mine in Bad Ischl, Austria [1,2]. The strain grew optimally at a salinity of $20 \%-25 \%$, a $\mathrm{pH}$ value of 7.4 and at $40{ }^{\circ} \mathrm{C}$. Subsequently, several halococcal strains were isolated from similar sites in England and Germany, which had identical 16S rRNA gene sequences and numerous similar properties as the Bad Ischl strain BIp ${ }^{\mathrm{T}}[3]$.

The genus Halococcus [4], emended by Oren et al. [5] currently comprises seven formally described species, which are listed here with their sites of isolation and reference in brackets: Hcc. morrhuae (seawater, saline lakes, salterns and salted products, [6]), Hcc. saccharolyticus (marine salterns, [7]), Hcc. salifodinae (rock salt from mines in Germany and Austria, also from brine in a salt mine in England, [1]), Hcc. dombrowskii (bore core from a salt mine in Austria, [8]), Hcc. hamelinensis (stromatolites of Shark Bay, Hamelin Pool in Western Australia, [9]), Hcc. qingdaonensis (crude sea-salt sample collected near Qingdao in Eastern China, [10]) and Hcc. thailandensis (fermented fish sauce produced in Thailand) [11]. Thus, two speciesHcc. salifodinae and Hcc. dombrowskii - were isolated from Permo-Triassic salt sediments, whereas the other five species can be regarded as inhabitants of hypersaline surface waters or heavily salted products.

A study by Wright [12] using 16S rRNA gene sequences of 61 haloarchaeal taxa, revealed that the mean genetic divergence over all possible pairs of halophilic archaeal $16 \mathrm{~S}$ rRNA gene sequences was $12.4 \pm 0.38 \%$, indicating close relatedness. In comparison, the greatest genetic divergence within methanogenic archaea was 34.2\% [12]. Within the halophilic archaea, Halococcus species form an even closer related group (see Figure 1), with 16S rRNA gene sequence similarities of $98.2 \%-98.7 \%$ between Hcc. thailandensis, Hcc. morrhuae, Hcc. qingdaonensis and Hcc. dombrowskii, and somewhat lower similarities of $93.7 \%-94.1 \%$ between Hcc. hamelinensis, Hcc. saccharolyticus and Hcc. salifodinae [11]. 
Figure 1. Distance-matrix neighbor-joining tree, showing the phylogenetic relationships of Halococcus type strains. The tree is based on an alignment of 16S rRNA gene sequences. Bootstrap values higher than 70 out of 1000 subreplicates are indicated at the respective bifurcations. The tree was constructed using the neighbour-joining method of Saitou and Nei [13]. The bar represents the scale of estimated evolutionary distance ( $1 \%$ substitutions at any nucleotide) from the point of divergence. Halobacterium noricense was used as an outgroup.

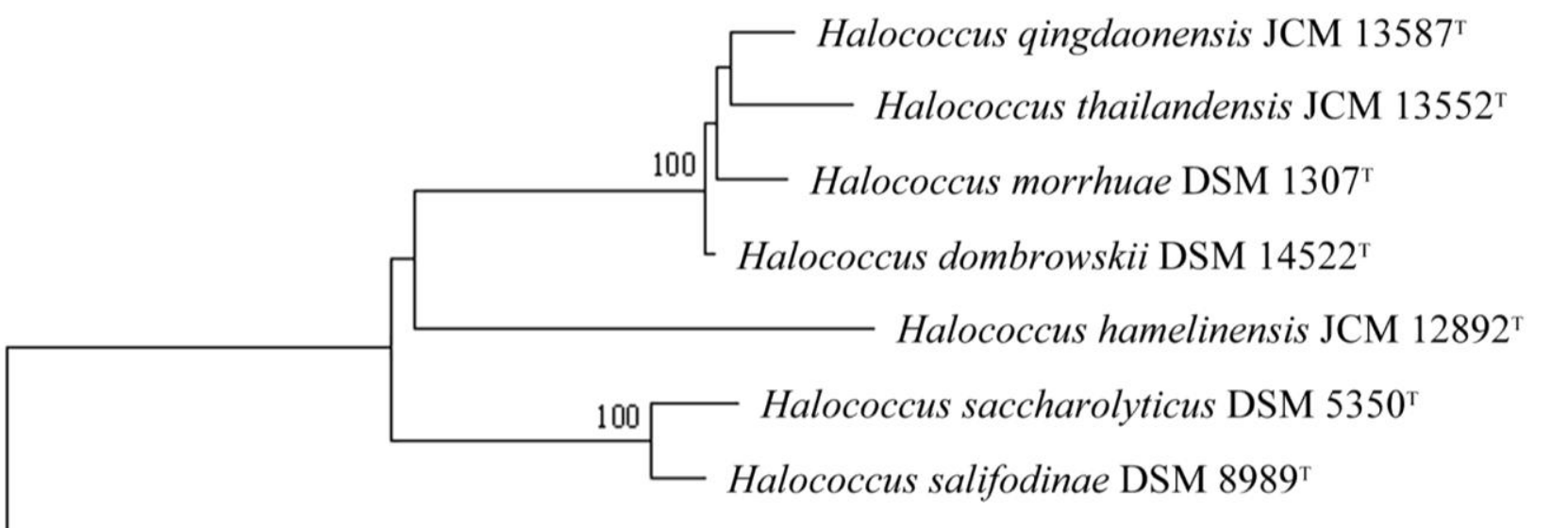

Halobacterium noricense DSM $15987^{\mathrm{T}}$



Our notions on prokaryotic evolution and evolution in general have been shaped by the concept of a molecular clock, which suggests an approximately uniform rate of molecular evolution among species and duplicated proteins over time [14]. Although subject to various criticisms, molecular-clock techniques still remain the only way to infer the timing of gene duplications and speciation events in the absence of fossil or biogeographical records [14]. The concept was applied previously to date the sequence divergences of halophilic archaeal protein-encoding genes, compared to the divergence of homologous non-halophilic eubacterial protein-encoding genes, assuming a point of haloarchaeal species diversion of 600 million years before present [15]. However, modern results from genome sequences revealed a much more complex history of life than can be depicted in bifurcating trees [16]. Widespread horizontal gene transfer-although occurring to different extents-, endosymbioses, gene losses and other processes cause the presence of different molecules with different histories in a species, and members of the same species were found to differ dramatically in gene content, leading to the suggestion of a fuzzy species concept in prokaryotes [16].

Some of these problems and uncertainties might be resolvable when viable microorganisms from well-dated ancient geological sites would be compared on a molecular basis with contemporary species. A crucial issue is the proof that microorganisms from ancient materials, like million year old deep subseafloor sediments, or Permian salt evaporites, are as old as the geological sites from which they were obtained (see [17-19] for discussions). The determination of the age of a single average bacterium is not possible with currently available methods, since its mass is only about a picogram. Thus, claims of ancient microorganisms were often dismissed as being due to laboratory contaminations. 
Recently, small particles of about $0.4 \mu \mathrm{m}$ in diameter were imaged by microscopy directly within fluid inclusions of 22,000-34,000 year old salt bore cores and, following successful culturing, identified as haloarchaea $[18,20]$. Embedding of halophilic microorganisms in fluid inclusions upon formation of salt crystals is well known, and fluid inclusions have been suggested as sites for preservation of microbial life [21-23]. In addition, Gramain et al. [24] reported isolation of haloarchaea from well-dated salt bore cores of Pliocene age (5.3 to 1.8 million years). Thus there is a growing body of evidence that haloarchaea survive for great lengths of time [24].

Here we review the properties of coccoid haloarchaea isolated from Permo-Triassic salt sediments, and relate them to those of halococci, which were isolated from surface waters. In addition, new data on Halococcus salifodinae concerning the chemical composition of its cell wall are included as well as DNA-DNA hybridization experiments between several strains of the species. Recently, the first genome sequence of a halococcus, Hcc. hamelinensis $100 \mathrm{~A} 6^{\mathrm{T}}$, became available [25] and therefore information for several genes ( $p h a C$ synthases; subunit A of the rotary A-ATPase) is examined here for their potential use in delineating the evolution of haloarchaeal cocci.

\section{Results and Discussion}

\subsection{General Description of halococci [26]}

Halococci are cells of 0.8-1.5 $\mu \mathrm{m}$ diameter, occurring in pairs, tetrads, sarcina packets, or large clusters [1,26]; see Figure 2, left panel. A striking difference to other genera of the Halobacteriaceae is their resistance to lysis in water (or generally hypotonic solutions). They are non-motile, strictly aerobic and extremely halophilic, requiring at least $2.5 \mathrm{M} \mathrm{NaCl}$ for growth and 3.5-4.5 $\mathrm{M} \mathrm{NaCl}$ for optimum growth [26]. Their optimum growth temperature is between $30-40{ }^{\circ} \mathrm{C}$ but most strains can grow up to $50^{\circ} \mathrm{C}$.

\subsection{Properties of Isolates from Permo-Triassic Salt Sediments and Surface Waters}

Following the formal description of Halococcus salifodinae BIp $^{T}$ DSM $8989^{T}$ as a novel species from a Permian salt deposit [1], a detailed comparison with similar isolates from a British halite formation (strain Br3) and from a bore core of the salt mine in Berchtesgaden, Germany (strain BG2/2) was undertaken [3]. In addition, two further isolates (strains H2, N1) from the Bad Ischl salt mine were similar enough to Hcc. salifodinae $\mathrm{BIp}^{\mathrm{T}}$ to consider them strains of the same species, obtained 8 years after the initial rock salt samples were taken [3]. The sequences of the 16S rRNA genes of all five strains were identical, as were their polar lipid composition, colonial and cellular morphology, cell size, cellular arrangement, and pigmentation. Strong similarities were found between whole-cell protein patterns, $\mathrm{G}+\mathrm{C}$ contents, growth characteristics, enzyme content and susceptibility to antibiotics. Table 1 provides a comparison of biochemical characteristics of the five strains of Hcc. salifodinae (numbered 1-5) with the other presently known six halococcal species (numbers 6-11). All strains of Hcc. salifodinae were positive for alkaline phosphatase, esterase (C4), esterase lipase (C8), oxidase and catalase (Table 1). Variable reactions among strains were observed for acid phosphatase, $\mathrm{N}$-acetyl- $\beta$-glucosaminidase, nitrate reduction, hydrolysis of Tween 20 and gelatine liquefaction (Table 1). Starch and Tween 80 were hydrolysed by strains $\mathrm{BIp}^{\mathrm{T}}, \mathrm{BG} 2 / 2$ and $\mathrm{Br}$, 
but casein was not. Goh et al. [9] reported that the two isolates of Hcc. hamelinensis were negative for oxidase activity, whereas Hcc. morrhuae NRC 16008, Hcc. saccharolyticus ATCC $49257^{\mathrm{T}}$ and Hcc salifodinae DSM $8989^{\mathrm{T}}$ were all positive. The API ZYM strips revealed that the two isolates of Hcc. hamelinensis were positive for leucine arylamidase, but negative for trypsin, as were all other halococci.

Table 1. Characteristics of five independently isolated strains of Halococcus salifodinae from three different locations [3] and other Halococcus species. 1, Hcc. salifodinae BIp ${ }^{\mathrm{T}}$ DSM $8989^{\mathrm{T}}$, type strain; 2, Hcc. salifodinae BG2/2 (DSM 13045); 3, Hcc. salifodinae Br3 (DSM 13046); 4, Hcc. salifodinae H2 (DSM 13071); 5, Hcc. salifodinae N1 (DSM 13070); 6, Hcc. saccharolyticus DSM 5350 (data from [26]); 7, Hcc. hamelinensis JCM $12892^{\mathrm{T}}$ (data from [9]); 8, Hcc. thailandensis (data from [11]); 9, Hcc. dombrowskii DSM $14522^{\mathrm{T}}$ (data from [8]); 10, Hcc. qingdaonensis JCM $13587^{\mathrm{T}}$ (data from [10]); 11, Hcc. morrhuae $\operatorname{DSM} 1307^{\mathrm{T}}$ (data from $[8,26]$ ).

\begin{tabular}{|c|c|c|c|c|c|c|c|c|c|c|c|}
\hline Characteristic* & $\mathbf{1}$ & $\mathbf{2}$ & $\mathbf{3}$ & $\mathbf{4}$ & $\mathbf{5}$ & $\mathbf{6}$ & $\mathbf{7}$ & $\mathbf{8}$ & $\mathbf{9}$ & $\mathbf{1 0}$ & $\mathbf{1 1}$ \\
\hline Oxidase & + & + & + & + & + & + & - & + & + & - & + \\
\hline Catalase & + & + & + & + & + & + & + & + & + & + & + \\
\hline Alkaline phosphatase & $(+)$ & + & + & + & + & & & & & & \\
\hline Esterase (C4) & + & + & + & + & + & & & & & & \\
\hline Lipase esterase (C8) & + & + & + & + & + & & & & & & \\
\hline Lipase (C14) & - & - & - & - & - & & & & & & \\
\hline Leucine arylamidase & - & - & - & - & - & & + & & & & \\
\hline Trypsin & - & - & - & - & - & & - & & & & \\
\hline Acid phosphatase & - & - & + & + & + & & & & + & & - \\
\hline Cystine arylamidase & - & - & - & - & - & & & & + & & - \\
\hline Nitrate reduction & + & + & + & - & + & + & & + & + & & + \\
\hline Gelatin liquefaction & + & - & - & & & $\mathrm{V}$ & - & - & + & - & $\mathrm{V}$ \\
\hline Hydrolysis of starch & + & + & + & & & - & + & - & & & $\mathrm{V}$ \\
\hline casein & - & - & - & & & - & & - & & & \\
\hline Tween 20 & - & + & + & & & & & - & & & \\
\hline Tween 80 & + & + & + & & & - & & & & - & + \\
\hline $\begin{array}{c}\text { Sensitivity to anti- } \\
\text { biotics: Tetracycline }\end{array}$ & + & + & + & + & + & - & - & - & - & - & - \\
\hline ": Chloramphenicol & + & + & + & + & + & - & & - & - & + & - \\
\hline ": Novobiocin & + & + & + & + & + & - & + & + & + & & + \\
\hline
\end{tabular}

$*+$, positive reaction; -, negative reaction; $(+)$ weak reaction; $v$, variable; empty box: no data available.

The results confirmed the assignment of strains 1-5 from salt deposits to the same species, Hcc. salifodinae. Hcc. salifodinae is distinct from other halococci, but, based on 16S rRNA sequences, appeared phylogenetically more closely related to Hcc. saccharolyticus. The similarity of the $16 \mathrm{~S}$ rDNA sequence of Hcc. salifodinae BIp ${ }^{\mathrm{T}}$ DSM $8989^{\mathrm{T}}$ to that of Hcc. saccharolyticus DSM $5350^{\mathrm{T}}$ was $98.9 \%$. A similarity value of $>97 \%$ necessitates the determination of the DNA-DNA homology by hybridization experiments, in order to delineate the identity of species [27]. Therefore, DNA-DNA hybridization between Hcc. salifodinae BIp ${ }^{\mathrm{T}}$ DSM $8989^{\mathrm{T}}$ and Hcc. saccharolyticus DSM $5350^{\mathrm{T}}$ was 
performed and showed a value of $63.6 \%$. DNA-DNA hybridization data confirmed that the two strains represent two different Halococcus species, since it is accepted that strains of a single species exhibit $\geq 70 \%$ DNA relatedness [28]. DNA-DNA hybridization was also carried out among the five Hcc. salifodinae strains and revealed values in the range of $82.6 \%$ to $95.0 \%$, corroborating the assignment of the strains to a single species. Thus it was demonstrated that in geographically separated halite deposits - located in Austria, Germany and England — of similar geological age, identical species of halococci are present. It can therefore be speculated that their native environment may have been the ancient Zechstein sea, spreading over large parts of what is now Europe [29] and it is tempting to suggest that they might be marker organism for salt deposits from certain geological periods [30].

\subsection{Cell Wall of Hcc. salifodinae}

The cell wall of Halococcus species is very prominent as seen in TEM micrographs (Figure 2, right panel; [1,3]) with a thickness of 50-60 nm reported for Hcc. morrhuae [31]. The material appears amorphous and the formation of septa is visible (white arrows).

Figure 2. Left panel: Scanning electron micrograph of Halococcus salifodinae Br3 (DSM 13046), grown in liquid culture medium [1]. Bar, $500 \mathrm{~nm}$. Right panel: Transmission electron micrograph of an ultrathin section of Halococcus salifodinae BIp ${ }^{\mathrm{T}}$ DSM $8989^{\mathrm{T}}$. Cells are surrounded by an amorphous layer of wall material. Septum formation is visible (white arrows). Bar, $760 \mathrm{~nm}$.

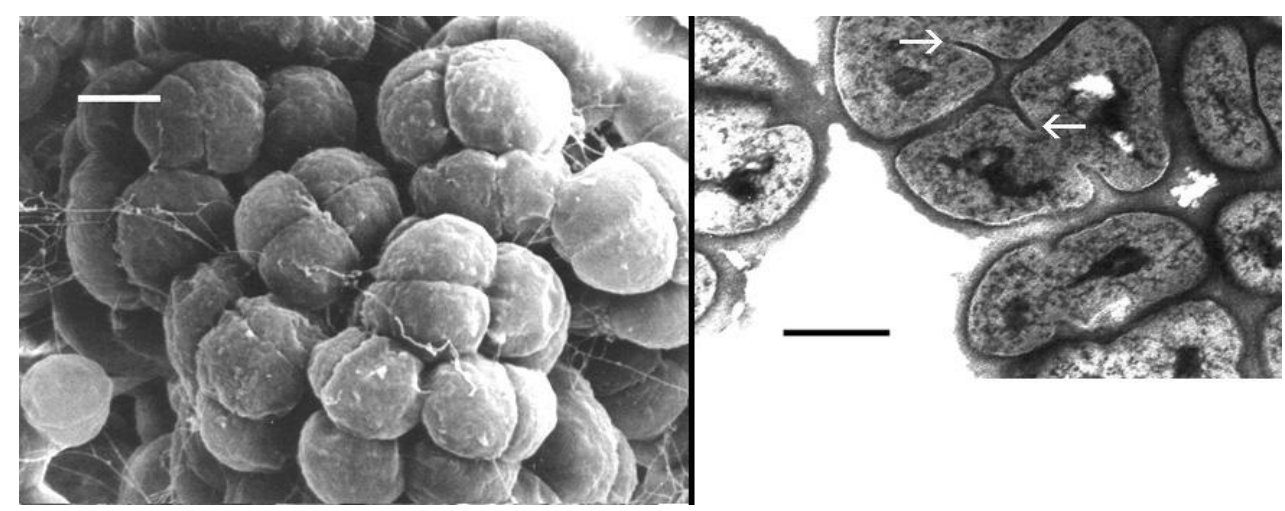

So far extremely halophilic Archaea are known to have developed three different cell wall types: (a) S-layers [32], (b) a heteropolysaccharide [33] and (c) a glutaminylglycan [34]. Layers of (glyco-) protein subunits (S-layers) represent the most common cell wall structures among Archaea [35,36]. The occurrence of S-layers, which were found in extremely halophilic archaeal genera such as Halobacterium and Haloferax [32] or several methanogenic genera such as Methanococcus [37] and Methanothermus [38] in the Euryachaeota branch, was not detected in Halococcus salifodinae. The chemical composition of only two cell walls from coccoid haloarchaea has been reported to date: Hcc. morrhuae CCM 859 possesses a heteropolysaccharide [33] and the haloalkalophile Natronococcus occultus contains a glutaminylglycan [34]. No molecular structures of these heteropolysaccharides are available yet. Since Hcc. salifodinae $\mathrm{BIp}^{\mathrm{T}}$ originated from an ancient habitat existing for about 250 million years, the cell surface structure of the organism was of special interest and the chemical composition of its cell wall was analyzed. 
No protein, as in S-layers, was found but instead, different monosaccharides were identified as constituents of the cell wall polymer, as was the case with the closely related species Halococcus morrhuae [33,39-41]. The results of the chemical analysis are summarized in Table 2. These data showed that the cell wall composition of Halococcus salifodinae is very similar to that of Halococcus morrhuae. Both cell wall polymers are composed of the neutral sugars galactose, mannose and glucose, the amino sugars glucosamine and galactosamine and the uronic acids glucuronic acid and galacturonic acid. Glycine and lysine were the only amino acids which could be detected in small amounts. However, the molar ratios of the cell wall constituents differed significantly between Hcc. morrhuae und Hcc. salifodinae.

Table 2. Chemical composition of the cell wall polymer of Halococcus morrhuae and Halococcus salifodinae.

\begin{tabular}{|c|c|c|}
\hline Cell wall constituents ${ }^{\mathrm{a}}$ & Hcc. morrhuae CCM $859^{\mathrm{b}}$ & Hcc. salifodinae $\mathrm{BIp}^{\mathrm{T}}$ DMS $8989^{\mathrm{T}}$ \\
\hline Glucose & 440 & 470 \\
\hline Mannose & 350 & 220 \\
\hline Galactose & 270 & 360 \\
\hline Ribose & n.d. & 60 \\
\hline Glucosamine & 380 & 180 \\
\hline Galactosamine & 200 & 80 \\
\hline Glucuronic acid & 470 & 60 \\
\hline Galacturonic acid & 200 & 20 \\
\hline Gulosaminuronic acid & 110 & n.d. \\
\hline Acetate & 620 & 660 \\
\hline Sulfate & 1470 & 1580 \\
\hline Phosphate & 120 & 130 \\
\hline Glycine & 100 & 7 \\
\hline Lysine & n.d. & 1 \\
\hline
\end{tabular}

These results allow us to speculate that a heteropolysaccharide forms the main cell wall polymer of Halococcus salifodinae, as was described for Halococcus morrhuae [33]. The carbohydrates of the cell wall sacculi of Halococcus morrhuae are arranged in three domains. These three domains are partly linked by N-glycyl-glucosaminyl bridges [41]. The data suggested that Halococcus salifodinae, a viable isolate from Permian rock salt deposits, has not developed a novel cell wall type, but possesses most likely a similarly structured, but modified heteropolysaccharide as the closely related species Halococcus morrhuae.

The coccus is the simplest of possible cell shapes. The coccoid morphology has been suggested as the first (bacterial) cell morphology [43], but later, arguments for a rod-shaped morphology were viewed as more likely, mainly a better surface to volume ratio, providing an increased area for uptake of nutrients [44]. Still, this issue has not been solved yet, and it will be interesting to see a comparison of the synthesis of peptidoglycan, the nearly ubiquitous cell wall polymer of bacteria, which is lacking in halococci [39], with that of heteropolysaccharides. Peptidoglycan in Gram-positive cells consists of a thick layer of several $\mathrm{nm}$ width, similar to the heteropolysaccharide layer of halococci [39]. Both 
polymers appear functionally identical, providing stability to the cell, both form septa during cell division (in contrast to constrictions of most Gram-negative bacteria), but, judging from their different compositions, their biochemical pathways must involve quite a different set of enzymes.

\subsection{Production of polyhydroxyalkanotes (PHA)}

Due to the considerable biotechnological and medical potential, the pathways of bacterial synthesis of polyhydroxyalkanotes (PHA) have been examined intensely (for a review see [45]). Accumulation of PHAs by haloarchaea was first reported by Fernandez-Castillo et al. [46]). So far, the best PHA producer of the family Halobacteriaceae is Haloferax mediterranei (see [47]). Recently, evidence for the production of polyhydroxyalkanoates by halococci was published ([48]), which included staining and electron microscopy of PHA granules as well as chemical identification by NMR from Hcc. morrhuae DSM $1307^{\mathrm{T}}$, Hcc. saccharolyticus DSM 5350 ${ }^{\mathrm{T}}$, Hcc. salifodinae BIp ${ }^{\mathrm{T}} \mathrm{DSM} 8989^{\mathrm{T}}$, Hcc. dombrowskii DSM $14522^{\mathrm{T}}$, Hcc. hamelinensis $\mathrm{JCM} 12892^{\mathrm{T}}$ and Hcc. qingdaonensis $\mathrm{JCM}$ $13587^{\mathrm{T}}$. Genetic information about haloarchaeal PHA synthases is still sparse. Of interest is the finding that high homologies exist to the bacterial enzymes as reported by several authors [47,49-52]. In a phylogenetic tree of PHA polymerases (phaC synthases), bacterial and haloarchaeal sequences clustered together, and the most closely affiliated microorganisms shared habitats of marine origin [47]. These observation suggested horizontal gene transfer [53]. It was even proposed that phaC synthases belonging to Class III of halophilic and non-halophilic microorganisms may have had a common ancestor [47].

\subsection{BLAST Search of Genes in the Genome of Hcc. hamelinensis.}

The genome sequence of Hcc. hamelinensis $100 \mathrm{~A} 6^{\mathrm{T}}$ has recently been published [25]. This allows preliminary comparisons with the genome content of other halococci, since as noted above, all halococci appear to be closely related. BLAST (Basic Local Alignment Search Tool [54]) searches were carried out with two examples, phaC (see 2.4.) and subunit A of the haloarchaeal ATPsynthase.

\subsubsection{Polyhydroxyalkanaote Synthase (phaC)}

The gene coding for phaC (polyhydroxyalkanaote synthase) from Haloferax mediterranei, accession number ACB10370 [52] was used with the program TBLASTN. The identities for the (translated) protein (492 amino acids) were 56\%, similarities were $71 \%$. A search with the nucleotide sequence for the related phaC (1425 nucleotides) of Haloarcula hispanica ATCC 33960 [52] resulted in $77 \%$ identities in the genome sequence of Hcc. hamelinensis $100 \mathrm{~A}^{\mathrm{T}}$.

\subsubsection{Subunit A (atpA) of the Archaeal ATP Synthase}

Fundamental enzyme complexes in all cells are the rotary ATP synthases/ATPases, which catalyze the synthesis of ATP at the expense of a proton or ion gradient and include three related members (for a recent review see [55]). The A-ATP synthase is present in archaea, which is similar to the eukaryotic V-ATPases. Preliminary information of the occurrence of A-ATPases in isolates from Permian salt sediments was obtained by immunological and biochemical properties with strain 54R, a 
close relative of the rod-shaped Halorubrum saccharovorum [56], whose ATPase has been characterized in detail [57,58]. However, no information exists yet about rotary ATPases from halococci. A BLAST search with the nucleotide sequence of subunit A of the A-ATPase from Halobacterium salinarum strain NRC-1 (NC_002607.1; length of 1758) revealed an identity of $81 \%$ in the genome sequence of Hcc. hamelinensis $100 \mathrm{~A} 6^{\mathrm{T}}$.

\subsection{Are Permo-Triassic Isolates Suitable for Evolutionary Studies?}

\subsubsection{What Type of Results Can be Expected?}

Using 16S rRNA sequences as a chronometer, Dennis and Shimmin [15] estimated that Halobacterium, Haloferax, and Haloarcula diverged from a common ancestor about $600 \times 10^{6}$ years ago. This calculation was based on the assumption of a constant and uniform rate of sequence diversions of $1 \%$ per $50 \times 10^{6}$ years [59]. This time frame appears rather short, since evidence (although disputed) for haloarchaeal DNA was found in Silurian salt sediments (416-429 million years old), some from Halobacterium species and some of unknown affiliation [60], perhaps from older and now extinct microorganisms. This type of questions may be answerable, i.e., the molecular clock concept could perhaps be verified, at least with highly conserved genes, when genome sequences of strains of Permo-Triassic origin are available. The evolution of biochemical pathways for cell wall synthesis or production of PHAs could be clarified (see above). Also, insights into the evolution of very complex cellular systems, e.g., ATP synthases, could be gained. Other expected results should be information about gene losses (see [16]), which could be detected with sequenced genomes of "ancient" subsurface prokaryotes. This could then explain unexpected phylogenetic results, for example, distribution of genes which do not fit a tree [16]. More information about horizontal gene transfer should probably become available.

\subsubsection{Which Strains Should be Used for Comparative Studies?}

Comparative 16S rRNA gene sequence analyses showed a similarity of $98.9 \%$ between Hcc. salifodinae $\mathrm{BIp}^{\mathrm{T}} \mathrm{DSM} 8989^{\mathrm{T}}$ and Hcc. saccharolyticus DSM 5350 ${ }^{\mathrm{T}}$. Thus, Hcc. saccharolyticus DSM $5350^{\mathrm{T}}$ would appear to be an appropriate counterpart for Hcc. salifodinae $\mathrm{BIp}^{\mathrm{T}} \mathrm{DSM} 8989^{\mathrm{T}}$ to carry out comparisons between a "contemporary" and a "Permian" genome, although the strains belong to different species, due to their DNA-DNA hybridization values of $<70 \%$ and several different phenotypic properties. A description of isolates from surface waters of salterns in Goa, India, showed other suitable candidates: halococcoid isolates were found with $98-99 \%$ similarities of $16 \mathrm{~S}$ rRNA genes to Hcc. salifodinae and Hcc. saccharolyticus [61]. From salt mines in Turkey, two halococcoid strains were obtained with $16 \mathrm{~S}$ rRNA similarities of $99.8 \%$ and $99.3 \%$, respectively, to Hcc. dombrowskii, and one pleomorphic strain with $99.7 \%$ similarity to Hbt. noricense [62]. Both Hcc. dombrowskii and Hbt. noricense originated also from Permo-Triassic salt sediments $[8,63]$. Detailed descriptions of all strains and whole genome sequences should yield meaningful comparisons. 


\section{Experimental Section}

Growth of microorganisms: Halococcus salifodinae strains $\mathrm{Blp}^{\mathrm{T}}$ (DSM 8989 ${ }^{\mathrm{T}}$ ), BG2/2 (DSM 13045), Br3 (DSM 13046), N1 (DSM 13070), H2 (DSM 13071), Hcc. morrhuae DSM 1307 ${ }^{\mathrm{T}}$, Hcc. saccharolyticus DSM $5350^{\mathrm{T}}$ and Hcc. dombrowskii DSM $14522^{\mathrm{T}}$ were grown in modified M2 medium as described by Denner et al. [1], which contained (g/l): yeast extract (5.0), casamino acids (5.0), $\mathrm{NaCl}$ (200.0), Tris/ $\mathrm{HCl}$ (12.1), $\mathrm{MgCl}_{2} \times 6 \mathrm{H}_{2} \mathrm{O}$ (20.0), $\mathrm{CaCl}_{2} \times 2 \mathrm{H}_{2} \mathrm{O}$ (2.0) and $\mathrm{KCl}(0.2)$ at $\mathrm{pH}$ 7.4. For testing the presence of polyhydroxyalkanoates, strains were also grown in synthetic medium with $1 \%(\mathrm{w} / \mathrm{v})$ glucose [64], except that $\mathrm{KBr}$ was used instead of $\mathrm{NaBr}$. Hcc. hamelinensis JCM $12892^{\mathrm{T}}$ and Hcc. qingdaonensis $\mathrm{JCM} 13587^{\mathrm{T}}$ were grown in complex medium (DSM no. 372 , http://www.dsmz.de/microorganisms/medium/pdf/DSMZ_Medium372.pdf). All cultures were incubated at $37^{\circ} \mathrm{C}$ with shaking at $180 \mathrm{rpm}$ in an Innova 4080 incubator (New Brunswick Scientific).

Preparation and analysis of cell walls: For preparation of cell walls, cultures were harvested by centrifugation at $8000 \mathrm{rpm}$ for $20 \mathrm{~min}$. The cell pellet was washed three times with deionized water and cells were disrupted with glass beads $(\varnothing 0.5-0.7 \mathrm{~mm})$ in a Braun cell homogenisator (model MKS) for $20 \mathrm{~min}$. The crude cell wall preparation was incubated overnight with trypsin $(0.5 \mathrm{mg} / \mathrm{ml}$; Merck) in a $0.05 \mathrm{M}(\mathrm{pH} 7.8)$ potassium phosphate buffer at $37^{\circ} \mathrm{C}$. Cell wall preparations were washed four times with deionized water and freeze-dried (Lyovac, Leybold-Heraeus). Neutral sugars and uronic acids were released from cell walls under vacuum with $2 \mathrm{M} \mathrm{HCl}$ at $100{ }^{\circ} \mathrm{C}$ for $2 \mathrm{~h}$ and $3 \mathrm{~h}$, respectively; amino sugars with $4 \mathrm{M} \mathrm{HCl}$ at $100{ }^{\circ} \mathrm{C}$ for $16 \mathrm{~h}$. After removal of the acid the aqueous uronic acid solution was adjusted to $\mathrm{pH} 9$ with an ammonia solution $(1 \mathrm{M})$ and incubated for $2 \mathrm{~h}$ at room temperature to delactonize. The compounds were identified and quantified by HPLC using a CarboPac ${ }^{\circledR}$ PA1 column (Dionex) and pulsed amperometric detection. Monosaccharides and amino sugars were separated with a gradient reaching from 16 to $300 \mathrm{mM} \mathrm{NaOH}$; for separation of uronic acids a gradient consisting of (A) $100 \mathrm{mM} \mathrm{NaOH}$ and (B) a solution of $100 \mathrm{mM} \mathrm{NaOH}$ with $1 \mathrm{M}$ sodium acetate was used. Acetate [65], sulfate [66] and phosphate [67] were determined by the described methods.

Enzyme tests: The API ZYM system (bioMerieux) was used for the identification of 19 enzymatic activities [68]. Test strips were inoculated with cells in the exponential phase of growth and were incubated at $37-39{ }^{\circ} \mathrm{C}$ for up to $24 \mathrm{~h}$ [8]. Standard tests (oxidase, catalase, nitrate reduction, gelatin liquefaction, hydrolysis of starch, casein and Tween) were performed as described previously [8] or as recommended by Oren et al. [69]. Tests were performed at least in triplicate.

DNA-DNA hybridization. DNA was isolated as described by Cashion et al. [70]. Levels of DNA-DNA hybridization were determined spectrophotometrically by the renaturation method of De Ley et al. [71], with the modifications by [72] and [73]. Renaturation rates were computed by the program TRANSFER.BAS [74]. These experiments were carried out by the Identification Service of the DSMZ, Braunschweig, Germany.

Other methods: For comparative phylogenetic analyses 16S rRNA gene sequences from validly described Halococcus spp. were obtained from the European Molecular Biology Laboratory (EMBL) web interface and fitted in a subset of aligned archaeal sequences obtained from the Ribosomal Database Project II [75]. Phylogenetic relationships of the sequences were constructed by using distance-matrix methods (corrections as in Jukes and Cantor [76]). The web-based software MEGA 2 
(http://www.megasoftware.net; [77]) and Clustal X [78] were used for sequence analysis and for construction of the phylogenetic tree, including maximum-likelihood and maximum parsimony methods. Confidence of the branching patterns was assessed by bootstrap analysis (1000 replicates). Scanning and transmission electron microscopy was performed as described previously $[1,3]$.

\section{Conclusions}

From considerations of close genetic relatedness and origin from ancient geological materials it is concluded that Halococcus salifodinae strains can be considered as living fossils and constitute a promising source of novel evolutionary information.

\section{Acknowledgments}

This work was supported in part by the Austrian Science Funds (FWF), projects P16260 and P18256 (to HSL). We thank Christiane Grünewald for excellent technical assistance.

\section{References}

1. Denner, E.B.M.; McGenity, T.J.; Busse, H.-J.; Wanner, G.; Grant, W.D.; Stan-Lotter, H. Halococcus salifodinae sp. nov., an archaeal isolate from an Austrian salt mine. Int. J. System. Bacteriol. 1994, 44, 774-780.

2. Radax, C.; Gruber, G.; Stan-Lotter, H. Novel haloarchaeal 16S rRNA gene sequences from Alpine Permo-Triassic rock salt. Extremophiles 2001, 5, 221-228.

3. Stan-Lotter, H.; McGenity, T.J.; Legat, A.; Denner, E.B.M.; Glaser, K.; Stetter, K.O.; Wanner, G. Very similar strains of Halococcus salifodinae are found in geographically separated Permo-Triassic salt deposits. Microbiol. 1999, 145, 3565-3574.

4. Schoop, G. Halococcus litoralis, ein obligat halophiler Farbstoffbildner. Dtsch Tierärztl Wochens 1935, 43, 817-820.

5. Oren, A.; Arahal, D.R.; Ventosa, A. Emended descriptions of genera of the family Halobacteriaceae. Int. J. Syst. Evol. Microbiol. 2009, 59, 637-642.

6. Kocur, M.; Hodgkiss, W. Taxonomic status of the genus Halococcus Schoop. Int. J. Syst. Bacteriol. 1973, 23, 151-156.

7. Montero, C.G.; Ventosa, A.; Rodriguez-Valera, F.; Kates, M.; Moldoveanu, N.; Ruiz-Berraquero, F. Halococcus saccharolyticus sp. nov., a new species of extremely halophilic non-alkaliphilic cocci. Syst. Appl. Microbiol. 1989, 12, 167-171.

8. Stan-Lotter, H.; Pfaffenhuemer, M.; Legat, A.; Busse, H.-J.; Radax, C.; Gruber, C. Halococcus dombrowskii sp. nov., an archaeal isolate from a Permian alpine salt deposit. Int. J. Syst. Evol. Microbiol. 2002, 52, 1807-1814.

9. Goh, F.; Leuko, S.; Allen, M.A.; Bowman, J.P.; Kamekura, M.; Neilan, B.A.; Burns, B.P. Halococcus hamelinensis sp. nov., a novel halophilic archaeon isolated from stromatolites in Shark Bay, Australia. Int. J. Syst. Evol. Microbiol. 2006, 56, 1323-1329.

10. Wang, Q.-F.; Li, W.; Yang, H.; Liu, Y.-L.; Cao, H.-H.; Dornmayr-Pfaffenhuemer, M.; Stan-Lotter, H.; Guo, G.-Q. Halococcus qingdaonensis sp. nov., a halophilic archaeon isolated from a crude sea-salt sample. Int. J. Syst. Evol. Microbiol. 2007, 57, 600-604. 
11. Namwong, S.; Tanasupawat, S.; Visessanguan, W.; Kudo, T.; Itoh, T. Halococcus thailandensis sp. nov., from fish sauce in Thailand. Int. J. Syst. Evol. Microbiol. 2007, 57, 2199-2203.

12. Wright, A.-D.G. Phylogenetic relationships within the order Halobacteriales inferred from $16 \mathrm{~S}$ rRNA gene sequences. Int. J. Syst. Evol. Microbiol. 2006, 56, 1223-1227.

13. Saitou, N.; Nei, M. The neighbor-joining method: A new method for reconstructing phylogenetic trees. Mol. Biol. Evol. 1987, 4, 406-425.

14. Kumar, S. Molecular clocks: four decades of evolution. Nat. Rev. Genetics 2005, 6, 654-662.

15. Dennis, P.P.; Shimmin, L.C. Evolutionary divergence and salinity-mediated selection in halophilic Archaea. Microb. Mol. Biol. Rev. 1997, 61, 90-104.

16. Gogarten, J.P.; Townsend, J.P. Horizontal gene transfer, genome innovation and evolution. Nat. Rev. Microbiol. 2005, 3, 679-687.

17. McGenity, T.J.; Gemmell, R.T.; Grant, W.D.; Stan-Lotter, H. Origins of halophilic microorganisms in ancient salt deposits. Environ. Microbiol. 2000, 2, 243-250.

18. Schubert, B.A.; Lowenstein, T.K.; Timofeeff, M.N.; Parker, M.A. Halophilic Archaea cultured from ancient halite, Death Valley, California. Environ. Microbiol. 2010, 12, 440-454.

19. Fendrihan, S.; Dornmayr-Pfaffenhuemer, M.; Gerbl, F.W.; Holzinger, A.; Grösbacher, M.; Briza, P.; Erler, A.; Gruber, C.; Plätzer, K.; Stan-Lotter, H. Spherical particles of halophilic Archaea correlate with exposure to low water activity - implications for microbial survival in fluid inclusions of ancient halite. Geobiology 2012, 10, 424-433.

20. Schubert, B.A.; Lowenstein, T.K.; Timofeeff, M.N. Microscopic identification of prokaryotes in modern and ancient halite, Saline Valley and Death Valley, California. Astrobiology 2009, 9, 467-482.

21. Norton, C.F.; Grant, W.D. Survival of halobacteria within fluid inclusions in salt crystals. J. Gen. Microbiol. 1988, 134, 1365-1373.

22. Mormile, M.R.; Biesen, M.A.; Gutierrez, M.C.; Ventosa, A.; Pavlovich, J.B.; Onstott, T.C.; Fredrickson, J.K. Isolation of Halobacterium salinarum retrieved directly from halite brine inclusions. Environ. Microbiol. 2003, 5, 1094-1102.

23. Fendrihan, S.; Legat, A.; Pfaffenhuemer, M.; Gruber, C.; Weidler, G.; Gerbl, F.; Stan-Lotter, H. Extremely halophilic archaea and the issue of long-term microbial survival. Rev. Environ. Sci. Biotech. 2006, 5, 203-218.

24. Gramain, A.; Chong Díaz G.C.; Demergasso, C.; Lowenstein, T.K.; McGenity, T.J. Archaeal diversity along a subterranean salt core from the Salar Grande (Chile). Environ. Microbiol. 2011, 13, 2105-2121.

25. Burns, B.P.; Gudhka, R.K.; Neilan, B.A. Genome sequence of the halophilic archaeon Halococcus hamelinensis. J. Bacteriol. 2012, 194, 2100-2101.

26. Grant, W.D.; Genus, I.V. Halococcus Schoop 1935a, 817 ${ }^{\mathrm{AL}}$. In Bergey's Manual of Systematic Bacteriology, 2nd ed.; Boone D.R., Castenholz, R.W., Garrity, G.M., Eds.; Springer-Verlag: New York, NY, USA, 2001; Volume 1, pp. 311-314.

27. Stackebrandt, E.; Goebel, B.M. Taxonomic note: a place for DNA-DNA reassociation and $16 \mathrm{~S}$ rRNA sequence analysis in the present species definition in bacteriology. Int. J. Syst. Bacteriol. 1994, 44, 846-849. 
28. Wayne, L.G.; Brenner, D.J.; Colwell, R.R.; Grimont, P.A.D.; Kandler, O.; Krichevsky, M.I.; Moore, L.H.; Moore, W.E.C.; Murray, R.G.E.; Stackebrandt, E.; Starr, M.P.; Trüper, H.G. International Committee on Systematic Bacteriology. Report of the ad hoc committee on reconciliation of approaches to bacterial systematics. Int. J. Syst. Bacteriol. 1987, 37, 463-464.

29. Zharkov, M.A. History of Paleozoic Salt Accumulation; Springer Verlag: Berlin, Germany, 1981.

30. Stan-Lotter, H.; Radax, C.; McGenity, T.J.; Legat, A.; Pfaffenhuemer, M.; Wieland, H.; Gruber, C.; Denner, E.B.M. From intraterrestrials to extraterrestrials - viable haloarchaea in ancient salt deposits. In Halophilic Microorganisms; Ventosa A., Ed.; Springer Verlag: New York, NY, USA, 2004; pp. 89-102.

31. Kocur, M.; Smid, B.; Martinec, T. The fine structure of extreme halophilic cocci. Microbios 1972, 5, 101-107.

32. Sumper, M.; Berg, E.; Mengele, R.; Strobel, I. Primary structure and glycosylation of the S-Layer protein of Haloferax volcanii. J. Bacteriol. 1990, 172, 7111-7118.

33. Schleifer, K.H.; Steber, J.; Mayer, H. Chemical composition and structure of the cell wall of Halococcus morrhuae. Zbl. Bakt. Hyg. 1. Abt. Orig. 1982, 3, 171-178.

34. Niemetz, R.; Kärcher, U.; Kandler, O.; Tindall, B.J.; König, H. The cell wall polymer of the extremely halophilic archaeon Natronococcus occultus. Eur. J. Biochem. 1997, 249, 905-911.

35. Kandler, O.; König, H. Cell envelopes of Archaebacteria. In The Bacteria vol. VII; Woese, C.R., Wolfe, R.S., Eds.; Academic Press: New York, NY, USA, 1985; pp. 413-457.

36. König, H.; Rachel, R.; Claus, H. Proteinaceous surface layers of Archaea: ultrastructure and biochemistry. In Archaea. Molecular Cell Biology; Cavicchioli, R., Ed.; ASM Press: Washington, DC, USA, 2007; pp. 315-340.

37. Claus, H.; Akca, E.; Debaerdemaeker, T.; Evrard, C.; Deqlercq, J.P.; Harris, J.R.; Schlott, B.; König, H. Molecular organization of selected prokaryotic S-layer proteins. Can. J. Microbiol. 2005, 51, 731-743.

38. Kärcher, U.; Schröder, H.; Haslinger, E.; Allmeier, G.; Schreiner, R.; Wieland, F.; Haselbeck, A.; König, H. Primary structure of the heterosaccharide of the surface glycoprotein of Methanothermus fervidus. J. Biol. Chem. 1993, 268, 26821-26826.

39. Brown, A.D.; Cho, K.Y. The walls of extremely halophilic cocci: Gram-positive bacteria lacking muramic acid. J. Gen. Microbiol. 1970, 62, 267-270.

40. Reistad, R. Cell wall of an extremely halophilic coccus. Investigation of ninhydrin-positive compounds. Arch. Microbiol. 1972, 82, 24-30.

41. Steber, J.; Schleifer, K.H. N-Glycyl-glucosamine, a novel constituent in the cell wall of Halococcus morrhuae. Arch. Microbiol. 1979, 123, 209-212.

42. Steber, J. Untersuchungen zur chemischen Zusammensetzung und Struktur der Zellwand von Halococcus morrhuae. PhD thesis, Technical University, Munich, Germany, 1976.

43. Koch, A.L. What size should a bacterium be? A question of scale. Annu. Rev. Microbiol. 1996, 50, 317-334.

44. Koch, A.L. Were Gram-positive rods the first bacteria? Trends Microbiol. 2003, 11, 166-170.

45. Rehm, H.A. Biogenesis of microbial polyhydroxyalkanoate granules: A platform technology for the production of tailor-made bioparticles. Curr. Issues Mol. Biol. 2007, 9, 41-62. 
46. Fernandez-Castillo, R.; Rodriguez-Valera, F.; Gonzales-Ramos, J.; Ruiz-Berraquero, F. Accumulation of poly( $\beta$-hydroxybutyrate) by halobacteria. Appl. Environ. Microbiol. 1986, 51, 214-216.

47. Quillaguamán J.; Guzmán, H.; Van-Thuoc, D.; Hatti-Kaul, R. Synthesis and production of polyhydroxyalkanoates by halophiles: current potential and future prospects. Appl. Microbiol. Biotechnol. 2010, 85, 1687-1696.

48. Legat, A.; Gruber, C.; Zangger, K.; Wanner, G.; Stan-Lotter, H. Identification of polyhydroxyalkanoates in Halococcus and other haloarchaeal species. Appl. Microbiol. Biotechn. 2010, 87, 1119-1127.

49. Baliga, N.S.; Bonneau, R.; Facciotti, M.T.; Pan, M.; Glusman, G.; Deutsch, E.W.; Shannon, P.; Chiu, Y.; Weng, R.S.; Gan, R.R.; Hung, P.; Date, S.V.; Marcotte, E.; Hood, L.; Ng, W.V. Genome sequence of Haloarcula marismortui: A halophilic archaeon from the Dead Sea. Genome Res. 2004, 14, 2221-2234.

50. Bolhuis, H.; Palm, P.; Wende, A.; Falb, M.; Rampp, M.; Rodriguez-Valera, F.; Pfeiffer, F.; Oesterhelt, D. The genome of the square archaeon Haloquadratum walsbyi: life at the limits of water activity. BMC Genomics 2006, 7, 169.

51. Han, J.; Lu, Q.; Zhou, L.; Zhou, J.; Xiang, H. Molecular characterization of the phaEC $\mathrm{Hm}_{\text {genes, }}$ required for biosynthesis of poly(3-hydroxybutyrate) in the extremely halophilic archaeon Haloarcula marismortui. Appl. Environ. Microbiol. 2007, 73, 6058-6065.

52. Lu, Q.; Han, J.; Zhou, L.; Zhou, J.; Xiang, H. Genetic and biochemical characterization of the poly(3-hydroxybutyrate-co-3-hydroxyvalerate) synthase in Haloferax mediterranei. J. Bacteriol. 2008, 190, 4173-4180.

53. Kalia, V.C.; Lal, S.; Cheema, S. Insight into the phylogeny of polyhydroxyalkanoate biosynthesis: horizontal gene transfer. Gene 2007, 389, 19-26.

54. Altschul, S.A.; Madden, T.L.; Schäffer, A.A.; Zhang, J.; Zhang, Z.; Miller, W.; Lipman, D.J. Gapped BLAST and PSI-BLAST: a new generation of protein database search programs. Nucleic Acids Res. 1997, 25, 3389-3402.

55. Muench, S.P.; Trinick, J.; Harrison, M.A. Structural divergence of the rotary ATPases. $Q$ Rev. Biophys. 2011, 44, 311-356.

56. Stan-Lotter, H.; Sulzner, M.; Egelseer, E.; Norton, C.F.; Hochstein, L.I. Comparison of membrane ATPases from extreme halophiles isolated from ancient salt deposits. Origins Life Evol. Biosphere. 1993, 23, 53-64.

57. Hochstein, L.I.; Kristjansson, H.; Altekar, W. The purification and subunit structure of a membrane-bound ATPase from the archaebacterium Halobacterium saccharovorum. Biochem. Biophys. Res. Commun. 1987, 147, 295-300.

58. Stan-Lotter, H.; Hochstein, L.I. A comparison of an ATPase from the archaebacterium Halobacterium saccharovorum with the $\mathrm{F}_{1}$ moiety from the Escherichia coli ATP synthase. Eur. J. Biochem. 1989, 179, 155-160.

59. Ochman, H.; Wilson, A. Evolution in bacteria: evidence for a universal rate in cellular genomes. J. Mol. Evol. 1987, 26, 74-86.

60. Park, J.S.; Vreeland, R.H.; Cho, B.C.; Lowenstein, T.K.; Timofeeff, M.N.; Rosenzweig, W.D. Haloarchaeal diversity in 23, 121 and 419 MYA salts. Geobiology 2009, 7, 515-523. 
61. Mani, K.; Salgaonkar, B.B.; Braganca, J.M. Culturable halophilic archaea at the initial and crystallization stages of salt production in a natural solar saltern of Goa, India. Aquat. Biosyst. 2012, $8,15$.

62. Yildiz, E.; Ozcan, B.; Caliskan, M. Isolation, characterization and phylogenetic analysis of halophilic Archaea from a salt mine in central Anatolia (Turkey). Polish J. Microbiol. 2012, 61, 111-117.

63. Gruber, C.; Legat, A.; Pfaffenhuemer, M.; Radax, C.; Weidler, G.; Busse, H.-J.; Stan-Lotter, H. Halobacterium noricense sp. nov., an archaeal isolate from a bore core of an alpine Permian salt deposit, classification of Halobacterium sp. NRC-1 as a strain of $H$. salinarum and emended description of $H$. salinarum. Extremophiles 2004, 8, 431-439.

64. Lillo, J.; Rodriguez-Valera, F. Effects of culture conditions on poly ( $\beta$-hydroxybutyric acid) production by Haloferax mediterranei. Appl. Environ. Microbiol. 1990, 56, 2517-2521.

65. Bergmeyer, H.U. Methoden der enzymatischen Analyse; Verlag Chemie: Weinheim, Germany, 1974.

66. Dodgston, K.S.; Price, R.G. A note on the determination of the ester sulphate content of sulphated polysaccharides. Biochem. J. 1962, 84, 106-110.

67. Chen, P.S.; Toribara, T.Y.; Warner, H. Microdetermination of phosphorus. Analyt. Chem. 1956, $28,1756-1758$.

68. Humble, M.W.; King, A.; Phillips, I. API ZYM: A simple rapid system for the detection of bacterial enzymes. J. Clin. Pathol. 1977, 30, 275-277.

69. Oren, A.; Ventosa, A.; Grant, W.D. Proposed minimal standards for description of new taxa in the order Halobacteriales. Int. J. Syst. Bacteriol. 1997, 47, 233-238.

70. Cashion, P.; Hodler-Franklin, M.A.; McCully, J.; Franklin, M. A rapid method for the base ratio determination of bacterial DNA. Anal. Biochem. 1977, 81, 461-466.

71. De Ley, J.; Cattoir, H.; Reynaerts, A. The quantitative measurement of DNA hybridisation from renaturation rates. Eur. J. Biochem. 1970, 12, 133-142.

72. Huß, V.A.R.; Festl, H.; Schleifer, K.H. Studies on the spectrometric determination of DNA hybridisation from renaturation rates. System. Appl. Microbiol.1983, 4, 184-192.

73. Escara, J.F.; Hutton, J.R. Thermal stability and renaturation of DNA in dimethylsulphoxide solutions: acceleration of renaturation rate. Biopolymers 1980, 19, 1315-1327.

74. Jahnke, K.-D. BASIC computer program for evaluation of spectroscopic DNA renaturation data from GILFORD System 2600 spectrometer on a PC/XT/AT type personal computer. J. Microbiol. Meth. 1992, 15, 61-73.

75. Maidak, B.L.; Cole, J.R.; Lilburn, T.G.; Parker, C.T., Jr.: Saxman, P.R.; Farris, R.J.; Garrity, G.M.; Olsen, G.J.; Schmidt, T.M.; Tiedje, J.M. The RDP-II (Ribosomal Database Project). Nucleic Acids Res. 2001, 29, 173-174.

76. Jukes, T.H.; Cantor, R.R. Evolution of protein molecules. In Mammalian Protein Metabolism; Munro, H.N, Ed.; Academic Press: New York, NY, USA, 1969; Volume 3, pp. 21-132.

77. Kumar, S.; Dudley, J.; Nei, M.; Tamura, K. MEGA: A biologist-centric software for evolutionary analysis of DNA and protein sequences. Brief Bioinform. 2008, 9, 299-306. 
78. Thompson, J.D.; Gibson, T.J.; Plewniak, F.; Jeanmougin, F.; Higgins, D.G. The CLUSTAL_X windows interface: Flexible strategies for multiple sequence alignment aided by quality analysis tools. Nucleic Acids Res. 1997, 25, 4876-4882.

(C) 2013 by the authors; licensee MDPI, Basel, Switzerland. This article is an open access article distributed under the terms and conditions of the Creative Commons Attribution license (http://creativecommons.org/licenses/by/3.0/). 